This is the author's final, peer-reviewed manuscript as accepted for publication. The publisher-formatted version may be available through the publisher's web site or your institution's library.

\title{
D-lactic acid biosynthesis from biomass-derived sugars via Lactobacillus delbrueckii fermentation
}

Yixing Zhang, Praveen V. Vadlani

\section{How to cite this manuscript}

If you make reference to this version of the manuscript, use the following information:

Zhang, Y., \& Vadlani, P. V. (2013). D-lactic acid biosynthesis from biomass-derived sugars via Lactobacillus delbrueckii fermentation. Retrieved from http://krex.ksu.edu

\section{Published Version Information}

Citation: Zhang, Y., \& Vadlani, P. V. (2013). D-lactic acid biosynthesis from biomassderived sugars via Lactobacillus delbrueckii fermentation. Bioprocess and Biosystems Engineering, 36(12), 1897-1904.

Copyright: @ Springer-Verlag Berlin Heidelberg 2013

Digital Object Identifier (DOI): doi:10.1007/s00449-013-0965-8

Publisher's Link: http://link.springer.com/article/10.1007/s00449-013-0965-8

This item was retrieved from the K-State Research Exchange (K-REx), the institutional repository of Kansas State University. K-REx is available at http://krex.ksu.edu 


\section{D-lactic acid biosynthesis from biomass-derived sugars}

3 Yixing Zhang $\cdot$ Praveen V. Vadlani *

4 Bioprocessing and Renewable Energy Laboratory, Department of Grain Science and

5 Industry, Kansas State University, Manhattan, Kansas. USA

6 *Corresponding Author, Tel: +1-785-532-5012; Fax: +1-785-532-7193; e-mail:

7 vadlani@ksu.edu 
1 Abstract Poly-lactic acid (PLA) derived from renewable resources is considered to be a

2 good substitute for petroleum-based plastics. The number of poly L-lactic acid

3 applications is increased by the introduction of a stereocomplex PLA, which consists of

4 both poly-L and D-lactic acid and has a higher melting temperature. To date, several

5 studies have explored the production of L-lactic acid, but information on biosynthesis of

6 D-lactic acid is limited. Pulp and corn stover are abundant, renewable lignocellulosic

7 materials that can be hydrolyzed to sugars and used in biosynthesis of D-lactic acid. In

8 our study, saccharification of pulp and corn stover was done by cellulase CTec2 and

9 sugars generated from hydrolysis were converted to D-lactic acid by a homofermentative

10 strain, L. delbrueckii, through a sequential hydrolysis and fermentation process (SHF)

11 and a simultaneous saccharification and fermentation process (SSF). $36.3 \mathrm{~g} \mathrm{~L}^{-1}$ of D-

12 lactic acid with $99.8 \%$ optical purity was obtained in the batch fermentation of pulp and

13 attained highest yield and productivity of $0.83 \mathrm{~g} \mathrm{~g}^{-1}$ and $1.01 \mathrm{~g} \mathrm{~L}^{-1} \mathrm{~h}^{-1}$, respectively.

14 Luedeking-Piret model described the mixed growth-associated production of D-lactic

15 acid with a maximum specific growth rate $0.2 \mathrm{~h}^{-1}$ and product formation rate $0.026 \mathrm{~h}^{-}$

$16^{1}$,obtained for this strain. The efficient synthesis of D-lactic acid having high optical

17 purity and melting point will lead to unique stereo-complex PLA with innovative

18 applications in polymer industry.

19 Keywords D-lactic acid, fermentation, corn stover, pulp, biosynthesis

20 List of symbols

$21 \mu_{\max }$ Maximum specific growth rate $\left(\mathrm{h}^{-1}\right)$

$22 \mathrm{C}_{0}$ Initial glucose concentration $\left(\mathrm{g} \mathrm{L}^{-1}\right)$

$23 \mathrm{C}_{\mathrm{p}}$ Product concentration $\left(\mathrm{g} \mathrm{L}^{-1}\right)$ 
$1 \quad Y_{\text {PS }}$ Product yield (g lactic acid g ${ }^{-1}$ glucose)

$2 \quad Y_{\text {PS }}^{\prime}$ Product overall yield (g lactic acid $\mathrm{g}^{-1}$ biomass)

$3 Y_{\mathrm{XS}}$ Yield of cell dry mass from substrate ( $\mathrm{g}$ cell dry mass $\mathrm{g}^{-1}$ glucose)

$4 Y_{\mathrm{PX}}$ Yield of product from cell dry mass (g D-lactic acid $\mathrm{g}^{-1}$ cell dry mass)

5 qPS Product formation rate $\left(\mathrm{h}^{-1}\right)$ calculated based on the equation $\mathrm{q}_{\mathrm{PS}}=\frac{1}{S} \times \frac{d P}{d t}$

$6 \quad \mathrm{Q}_{\mathrm{p}}$ Productivity $\left(\mathrm{g} \mathrm{L}^{-1} \mathrm{~h}^{-1}\right)$

7 


\section{Introduction}

2 Lignocellulosic biomass is gaining importance as a potential source of renewable energy

3 and chemicals as the fossil fuel reserves are eventually getting depleted. Demand

4 continues to increase for production of high-value chemicals and materials from

5 renewable resources to attain domestic self-sufficiency and enhanced national security.

6 Lactic acid is an important and multifunctional organic acid that has wide applications in

7 the food, pharmaceutical, and chemical industries [1,2]. It exists in two optical isomeric

8 forms, L (+) and D (-) poly-lactic acid (PLA), which are being developed as a substitute

9 for petroleum-derived plastics. The high chemical resistance of poly lactic acid is

10 advantageous in the manufacture of fibers, nonwoven fabrics, and films [3]; however, the

11 application of poly L-lactic acid (PLLA) is limited by its melting point [4]. This problem

12 can be obviated by blending it with poly D-lactic acid (PDLA). The melting point of the

13 resulting stereocomplex polymer is approximately $50{ }^{\circ} \mathrm{C}$ higher than that of the

14 respective single polymers [5]. The optical purity of lactic acid accentuates the physical

15 properties of poly D-lactic acid-based polymers [6]. The chemical process of making

16 lactic acids usually yields a mixture of these two enantiomers, which is an undesirable

17 feature; therefore, the biological process of making pure lactic acid is preferred [7].

18 To date, intense studies have been conducted on the production of L-lactic acid from

19 different biomass through microbial fermentation [8-11], but information on biosynthesis

20 of D-lactic acid from biomass is limited. A few wild-type strains such as Lactobacillus

21 delbrueckii subsp. delbrueckii, Sporolactobacillus inulinus [12], Lactobacillus

22 coryniformis subsp. torquens [13], and Lactobacillus delbrueckii subsp. lactis QU41 [14] 
1 have been identified as D-lactic acid producers. Traditional production of lactic acids

2 typically uses starch derived from food crops as the fermentation substrate [12, 15], but

3 this process may affect the global food supply. Lignocellulosic materials are favorably

4 structured to produce lactic acids, which require the breakdown of cellulose to sugars

5 [16]. This step usually can be done by acid hydrolysis and enzymatic hydrolysis. The

6 enzymatic hydrolysis method is preferred, because it can be done under mild reaction

7 conditions avoiding the use of toxic and corrosive chemicals [17]. The hydrolysis and

8 fermentation steps can be done sequentially (SHF) or simultaneously (SSF). The SSF

9 process offers better yields because it avoids product inhibition and results in higher

10 productivity $[18,19]$.

11 Production of D-lactic acid from cardboard [20, 21], cellulose [13], peanut meal [22], and

12 rice bran [3] has been studied. Other sources include pulp and corn stover, which have

13 the potential to become cheap and abundant sources for production of ethanol, organic

14 acids, and other chemicals $[7,21]$. Pulp is prepared by chemically or mechanically

15 separating cellulose fibers from wood, fiber crops, or waste paper [23]. Corn stover,

16 which includes the leaves, stalks, and cobs of corn plant, is the most abundant

17 agricultural residue in the U.S. [24]; to the best of our knowledge, no research has been

18 reported on D-lactic acid fermentation via pulp and corn stover as substrates.

19 The purpose of this study was to produce D-lactic acid with high yield and optical purity

20 from pulp and corn stover by lactobacillus delbrueckii ATCC 9649. L. delbrueckii is a

21 homofermentative lactic acid bacterium that can provide a continuous bioprocess with

22 high volumetric productivity and optically high purity of D-lactic acid under anaerobic 
1 conditions [25]. In addition, kinetic analyses of enzyme hydrolysis and fermentation of

2 glucose to D- lactic acid also have been studied in this work.

\section{Materials and methods}

4 Raw materials and chemical treatment

5 Regular pulp and mechanically modified pulp were obtained from the MeadWestvaco's

6 Crompton mill. Corn stover was obtained from fields in Manhattan and Tribune, Kansas.

7 Alkali treatment was performed on corn stover before hydrolysis. Corn stover was

8 suspended in $20 \mathrm{~g} \mathrm{~L}^{-1} \mathrm{NaOH}$ and heated at $121{ }^{\circ} \mathrm{C}$ for $30 \mathrm{~min}$ in an autoclave (Tomy SS-

9 325E, Tomy SEKO CO., LTD, Tokyo, Japan), then washed under running distilled water

10 and filtered through muslin cloth until no color was visible in the wash water. The alkali-

11 treated corn stover was dried at $80{ }^{\circ} \mathrm{C}$ for $24 \mathrm{~h}$ and ground to fine particle size in a

12 laboratory mill (3303, Perten Instruments, Springfield, IL) for further enzymatic

13 hydrolysis.

14 Enzyme hydrolysis

15 CTec2 (cellulase) obtained from Novozymes Inc. (Franklinton, NC) was used in this

16 experiment. Enzyme hydrolysis assays were carried out at $45^{\circ} \mathrm{C}$ in $250 \mathrm{~mL}$ screw capped

17 plastic conical flasks with orbital agitation (150 rpm). The substrate concentration was $2 \%$

18 (w/v). $\mathrm{pH}$ was kept at 4.8 using $0.05 \mathrm{~mol} \mathrm{~L}^{-1}$ citric acid-sodium citrate buffer. The

19 cellulase activity of CTec2 was measured by the filter paper assay [26], and the activity

20 was expressed in terms of filter paper units (FPU). CTec2 was added on a dosage of 2, 4, 
1 and 8 FPU g ${ }^{-1}$ of dry biomass, respectively. Product yield is based on the amount of

2 glucose released divided by the amount of biomass consumed.

3 Microorganism and culture conditions

4 Lactobacillus delbrueckii ATCC 9649 obtained from the American Type Culture

5 Collection (Manassas, VA) was used in this work. L. delbrueckii inoculum was prepared

6 by growing cells in a $100 \mathrm{~mL}$ Wheaton serum bottle containing $50 \mathrm{~mL}$ of liquid MRS

7 medium (MRS broth, Difco Laboratories, Detroit, MI) and incubated at $37{ }^{\circ} \mathrm{C}$ in a

8 temperature-controlled shaker (Innova 4300, New Brunswick scientific, NJ) at $120 \mathrm{rpm}$

9 for $15 \mathrm{~h} . \mathrm{CO}_{2}(3 \mathrm{vvm})$ was sparged into the bottle to create anaerobic growing conditions.

\section{Sequential hydrolysis and fermentation (SHF)}

11 Shake flask fermentation was modified according to the procedure described by 12 Mukhopadhyay [27]. Fermentation was performed in $100 \mathrm{~mL}$ Wheaton serum bottles 13 containing $50 \mathrm{~mL}$ of synthetic medium, pulp, modified pulp, or corn stover hydrolyzate,

14 and lasted for $30 \mathrm{~h}$. The synthetic medium consisted of $10 \mathrm{~g} \mathrm{~L}^{-1}$ of glucose, $10 \mathrm{~g} \mathrm{~L}^{-1}$ of 15 peptone, $5 \mathrm{~g} \mathrm{~L}^{-1}$ of yeast extract, $2 \mathrm{~g} \mathrm{~L}^{-1}$ of ammonium citrate, $2 \mathrm{~g} \mathrm{~L}^{-1}$ of sodium acetate, 2

$16 \mathrm{~g} \mathrm{~L}^{-1}$ of ammonium citrate, $2 \mathrm{~g} \mathrm{~L}^{-1}$ of $\mathrm{K}_{2} \mathrm{HPO}_{4}, 0.1 \mathrm{~g} \mathrm{~L}^{-1}$ of $\mathrm{MgSO}_{4} .7 \mathrm{H}_{2} \mathrm{O}, 0.05 \mathrm{~g} \mathrm{~L}^{-1}$ of

$17 \mathrm{MnSO}_{4} \cdot 4 \mathrm{H}_{2} \mathrm{O}$, and $1 \mathrm{~g} \mathrm{~L}^{-1}$ of Tween 80 . Pulp, modified pulp, and corn stover hydrolyzate

18 were supplemented with all the components (except glucose) of the synthetic medium.

$19 \mathrm{pH}$ of the media was adjusted to 6.5 by $10 \mathrm{~mol} \mathrm{~L}^{-1} \mathrm{NaOH}$, and $3 \%(\mathrm{w} / \mathrm{v})$ of calcium

20 carbonate was added to control the $\mathrm{pH}$. Temperature was maintained at $37{ }^{\circ} \mathrm{C}$, and

21 agitation was $120 \mathrm{rpm}$. Batch and fed-batch fermentation were performed in a $7 \mathrm{~L}$

22 fermenter with a working volume of 5 L (Bioflo 110, New Brunswick Scientific Inc. 
1 Enfield, CT). In the batch fermentation experiment, paper pulp was added in quantity

2 (270 g) that would possibly achieve a glucose concentration of $40 \mathrm{~g} \mathrm{~L}^{-1}$ in the medium.

3 After hydrolysis, the pulp hydrolyzate was supplemented with all the components (except

4 glucose) of the synthetic medium. The synthetic medium was used in fed-batch

5 fermentation as a control. After $36 \mathrm{~h}, 1 \mathrm{~L}$ of fermentation medium was taken out and $1 \mathrm{~L}$

6 of feeding medium, which consisted of $40 \mathrm{~g} \mathrm{~L}^{-1}$ of glucose, $2 \mathrm{~g} \mathrm{~L}^{-1}$ of ammonium citrate,

$72 \mathrm{~g} \mathrm{~L}^{-1}$ of sodium acetate, $2 \mathrm{~g} \mathrm{~L}^{-1}$ of ammonium citrate, $2 \mathrm{~g} \mathrm{~L}^{-1}$ of $\mathrm{K}_{2} \mathrm{HPO}_{4}, 0.1 \mathrm{~g} \mathrm{~L}^{-1}$ of

$8 \mathrm{MgSO}_{4} .7 \mathrm{H}_{2} \mathrm{O}$, and $0.05 \mathrm{~g} \mathrm{~L}^{-1}$ of $\mathrm{MnSO}_{4} .4 \mathrm{H}_{2} \mathrm{O}$, was added. During the fermentation, the

9 temperature was maintained at $37^{\circ} \mathrm{C}$; agitation speed at $100 \mathrm{rpm}$; and $\mathrm{pH}$ at $6.5 . \mathrm{CO}_{2}$ was

10 sparged at $3 \mathrm{vvm}$ through the vessel to maintain anaerobic conditions.

11 Simultaneous saccharification and fermentation (SSF)

12 SSF process was modified according to the procedure described by Mukhopadhyay

13 [27]The optimal temperature and $\mathrm{pH}$ for the enzymatic hydrolysis and the bacterial

14 fermentation are different; In SSF, temperature was at $40{ }^{\circ} \mathrm{C}$ and $\mathrm{pH}$ was at 5.5 , which

15 were conducive for both enzymatic hydrolysis and bacterial activity. $2 \mathrm{~g}$ of dried pulp

16 and corn stover was suspended in $50 \mathrm{ml} 0.05 \mathrm{~mol} \mathrm{~L}^{-1}$ sodium citrate buffer (pH 5.5) with

17 all the components (except glucose) of the synthetic medium. $3 \%(\mathrm{w} / \mathrm{v})$ calcium carbonate

18 was added to control the $\mathrm{pH}$. CTec2 was added at $8 \mathrm{FPU} \mathrm{g}^{-1}$ of biomass, and

19 L.delbrueckii was inoculated at $5 \%(\mathrm{v} / \mathrm{v})$, and agitation rate was $150 \mathrm{rpm}$. 
1 Analyses

2 Fermentation samples were centrifuged at $15,000 \times \mathrm{g}$ for $10 \mathrm{~min}$ in an Eppendorf 3 centrifuge (5415R, Eppendorf, Hauppauge, NY). The supernatant was collected in

4 sample vials and stored at $-4{ }^{\circ} \mathrm{C}$ for product and residue glucose analyses.

5 Sugars were quantified by a binary HPLC system (Shimadzu Scientific Instruments,

6 Columbia, MD) equipped with a refractive Index detector (RID-10A) and phenomenex

7 RPM monosaccharide column $(300 \times 7.8 \mathrm{~mm}$, Phenomenex, Torrance, CA $)$. Deionised

8 water was used as the mobile phase at a flow rate of $0.6 \mathrm{~mL} \mathrm{~min}^{-1}$. The oven (Prominence

9 CTD-20A) temperature was maintained at $80{ }^{\circ} \mathrm{C}$.

10 Lactic acids were quantified by a Chirex Chiral column $(150 \times 4.6 \mathrm{~mm}$, Phenomenex,

11 Torrance, CA) with isocratic $1 \mathrm{mmol} \mathrm{L}^{-1}$ copper (II) sulfate mobile phase at $1 \mathrm{~mL} \mathrm{~min}^{-1}$.

12 Peaks were monitored using a UV detector at $254 \mathrm{~nm}$ (Shimadzu, PDA).

\section{Results and discussion}

\section{Enzymatic hydrolysis}

15 Experiments with different loads of cellulase were performed to determine a suitable

16 enzyme loading for enzymatic hydrolysis of pulp, modified pulp, and alkali-treated corn

17 stover. The maximum reaction rate $\left(\mathrm{v}_{\max }\right)$ was calculated from the Michaelis-Menten

18 equation $\left(v=\frac{v_{\max }[S]}{K_{m}+[S]}\right) . v_{\max }$ increased almost linearly with the increase of enzyme

19 concentration in all three biomass cases (Fig. 1). The hydrolysis rate of corn stover and

20 modified pulp was about to reach a plateau when the enzyme loading increased, perhaps

21 due to substrate saturation [28]. Increased enzyme loading from 2 to $8 \mathrm{FPU} \mathrm{g}^{-1}$ of 
1 substrate increased glucose yield by $24 \%$ after $48 \mathrm{~h}$ of pulp saccharification (Fig.2a);

2 however, increasing the enzyme dosage did not significantly change the final glucose

3 yield in the saccharification of mechanically modified pulp (12\%) (Fig. 2b) and alkali

4 treated corn stover (11\%) (Fig. 2c). The highest glucose yield was observed at $24 \mathrm{~h}$ for

5 mechanically modified pulp as well as corn stover. The initial saccharification rate of

6 mechanically modified pulp and corn stover was higher than that of pulp. Mechanically

7 modified pulp had finer fiber size, which made it much easier for the enzymes to break

8 down. Alkali treatment caused the cellulose in corn stover to swell, which led to an

9 increase in the internal surface area and a decrease in the degree of crystallinity of

10 cellulose [29], therefore making cellulose in alkali-treated corn stover much easier for the

11 enzyme to access.

\section{Production of D-lactic acid by SHF}

13 The purpose of this portion of the study was to produce D-lactic acid by L. delbrueckii

14 using sugars derived from biomass as a cheap carbon source. We also tested another

15 strain Sporolactobacillus inulinus ATCC 15538. Unlike in the results obtained by

16 Fukushima et al. [12], S. inulinus produced L-lactic acid instead of D-lactic acid in our

17 experiments. This result may be due to the difference in strain or the possible alternation

18 of bacterial character after receiving it.

19 In shake flask fermentation, the amount of pulp (1 g), mechanically modified pulp (1.3 g),

20 and corn stover (1.2 g) was set up to obtain $10 \mathrm{~g} \mathrm{~L}^{-1}$ glucose after enzymatic hydrolysis.

21 No residual glucose was observed after $30 \mathrm{~h}$ fermentation, and the final $\mathrm{pH}$ of the 22 medium was between 5 to 5.5 . The optical purity of D-lactic acid was $99.9 \%$. These 
1 results were in close agreement with Demirci and Pometto [30]. The highest yield of D-

2 lactic acid was observed in corn stover hydrolyzate (Table 1). Besides glucose, $5.6 \mathrm{~g} \mathrm{~L}^{-1}$

3 xylose and $1.7 \mathrm{~g} \mathrm{~L}^{-1}$ arabinose were also present in the corn stover hydrolyzate; however,

4 xylose remained unused, and arabinose was below detectable levels at the end of

5 fermentation. L.delbrueckii cannot use xylose due to the lack of xylose isomerase and

6 xylulokinase, two key enzymes in xylose assimilation [31].

7 In fed-batch fermentation, almost all glucose was consumed within the first $36 \mathrm{~h}$ (first

8 stage). In the second stage, feeding medium was added, and fermentation was completed

9 within $80 \mathrm{~h}$. The Luedeking-Piret equation $\left(\frac{1}{X} \frac{d P}{d t}=\alpha \frac{1}{X} \frac{d X}{d t}+\beta\right)$ was used to describe

10 the D-lactic acid production from synthetic medium in the first stage. Growth-associated

11 constant $(\alpha)$ and non-growth associated constant $(\beta)$ can be calculated from the graph of

12 the specific production rate $\left(\mathrm{q}_{\mathrm{p}}\right)$ versus the specific growth rate $(\mu)$; the correlation

13 coefficient $\left(\mathrm{R}^{2}\right)$ was 0.88 (Fig. 3). Compared with other strains listed in Table 2, in our

14 study L. delbrueckii had lower $\mu_{\max }$ and higher $\alpha$ values. Lower $\mu_{\max }$ suggests lower

15 growth efficiency, and a high $\alpha$ value indicates a higher contribution of the cell growth to

16 D-lactic acid production [32]. The value of $\alpha$ multiplied by $\mu_{\max }$ was 1.56 , which was

17 larger than the $\beta$ value, indicating that the specific growth rate played an important role in

18 specific D-lactic acid production.

19 Figures 4 and 5 show the fermentation profile of the synthetic medium and pulp

20 hydrolyzate, respectively. Table 3 summarizes the results of the first stage of fed-batch

21 fermentation and batch fermentation. $37.4 \mathrm{~g} \mathrm{~L}^{-1}$ of D-lactic acid was obtained by the end

22 of first-stage fermentation, and the product yield and productivity obtained were $0.93 \mathrm{~g} \mathrm{~g}^{-}$ 
$1{ }^{1}$ and $1.04 \mathrm{~g} \mathrm{~L}^{-1} \mathrm{~h}^{-1}$, respectively. These results were in agreement with other studies in

2 literature [8,33]. Fed-batch fermentation was completed within $80 \mathrm{~h}$; at the end of

3 fermentation, about $5.5 \mathrm{~g} \mathrm{~L}^{-1}$ glucose was left and up to $57.3 \mathrm{~g} \mathrm{~L}^{-1} \mathrm{D}$-lactic acid with

4 optical purity of $99.8 \%$ was accumulated, which led to a productivity of $0.72 \mathrm{~g} \mathrm{~L}^{-1} \mathrm{~h}^{-1}$.

5 After pulp hydrolysis, the glucose concentration was $50 \mathrm{~g} \mathrm{~L}^{-1}$ and was used in the batch

6 fermentation. After $30 \mathrm{~h}$, glucose was hardly consumed, and even if we extended the

7 fermentation time to $36 \mathrm{~h}, 6.2 \mathrm{~g} \mathrm{~L}^{-1}$ residual glucose remained. At the end of fermentation,

$8 \quad 36.3 \mathrm{~g} \mathrm{~L}^{-1}$ lactic acid was produced, the yield of D-lactic acid was calculated by the

9 amount of D-lactic acid produced divided by the amount of glucose consumed, which

10 was $0.83 \mathrm{~g} \mathrm{~g}^{-1}$, and productivity was $1.01 \mathrm{~g} \mathrm{~L}^{-1} \mathrm{~h}^{-1}$. In a similar study undertaken in our

11 laboratory, L-Lactic acid was synthesized from cheese whey and a yield $\left(0.98 \mathrm{~g} \mathrm{~g}^{-1}\right)$ and

12 productivity $\left(1.14 \mathrm{~g} \mathrm{~L}^{-1} \mathrm{~h}^{-1}\right)$ was obtained [8]. The product formation rate of batch

13 fermentation of pulp hydrolyzate was quite close to the product formation rate of first-

14 stage fed-batch fermentation using the synthetic medium. The yield of D-lactic acid $(0.83$

$\left.15 \mathrm{~g} \mathrm{~g}^{-1}\right)$ from pulp hydrolyzate was lower than the first-stage yield $\left(0.93 \mathrm{~g} \mathrm{~g}^{-1}\right)$ from

16 synthetic medium. The reason might be due to substrate inhibition; therefore, the SSF

17 process was preferred in subsequent experiments.

18 Production of D-lactic acid by SSF

19 After demonstrating the feasibility of producing D-lactic acid from biomass hydrolyzate

20 in the batch process, SSF was carried out using pulp and corn stover in a shake flask. In

21 SSF, samples were collected after $4 \mathrm{~h}$ of incubation; the profiles obtained for corn stover

22 and pulp SSF experiments are shown in Figure 6.. In SSF, cellulose hydrolysis and 
1 glucose assimilation were combined into a single fermentation process [34]. During the

2 first $8 \mathrm{~h}$, bacteria were in low activity and glucose accumulated to around $8 \mathrm{~g} \mathrm{~L}^{-1}$ and $14 \mathrm{~g}$

$3 \mathrm{~L}^{-1}$ in the case of pulp and corn stover, respectively. After the first $8 \mathrm{~h}$ cultivation,

4 glucose concentration was kept low, which indicated that bacterial cells were

5 metabolically active during the entire course of the fermentation and also meant that

6 enzymatic hydrolysis of cellulose was the rate limiting step for D-lactic acid production

7 as already observed by other groups [35, 36]. Xylose accumulated and remained nearly

8 constant throughout the process. It was impossible to know the exact amount of glucose

9 consumed in the SSF process; therefore, in order to compare SSF and SHF, results were

10 expressed as an overall yield (the amount of D-lactic acid produced divided by the

11 amount of biomass used)(Table 1). The highest D-lactic acid overall yield was 0.48 and

$120.38 \mathrm{~g} \mathrm{~g}^{-1}$ of pulp in SSF and SHF, respectively. For corn stover, the maximum D-lactic

13 acid overall yield was 0.58 and $0.41 \mathrm{~g} \mathrm{~g}^{-1}$ in SSF and SHF, respectively, demonstrating

14 that the SSF process was more efficient than the SHF process. The reason for the higher

15 overall yield in SSF may be that glucose released during the hydrolysis step was rapidly

16 consumed as substrate during the fermentation step, therefore reducing the end-product

17 inhibition of hydrolysis [37].

\section{Conclusions}

19 In this study, we demonstrated efficient D-lactic acid production with high optical purity

20 from pulp, modified pulp, and corn stover by L. delbrueckii ATCC 9649. Enzymatic

21 hydrolysis of biomass was achieved effectively by CTec2 enzyme system. D-lactic acid

22 productivity was not only high, but also cost-effective because pulp and modified pulp 
1 need no pretreatment. The SSF process demonstrated the advantages of avoiding

2 substrate inhibition and increasing the productivity and yield of D-lactic acid. The yield

3 obtained in the present study would have been even higher if xylose from corn stover

4 hydrolyzate could be completely used by the microorganism. Future study should be

5 directed toward complete use of the available carbohydrate for efficient D-lactic acid

6 production.

\section{Acknowledgements}

8 This work was funded by the Consortium for Plant Biotechnology Research and

9 supported by the Department of Grain Science and Industry at Kansas State University.

10 The authors are grateful to Novozymes Inc. for the donation of enzymes. This is

11 contribution number 13-180-J from the Kansas Agricultural Experiment Station.

13 References

14 1. Shen X, Xia L (2006) Lactic acid production from cellulosic material by synergetic

15 hydrolysis and fermentation. Appl Biochem Biotechnol 133:251-262

16 2. Datta R, Tsai S, Bonsignore P, Moon S, Frank J (1995) Technological and Economic-

17 Potential of Poly (lactic Acid) and Lactic-Acid Derivatives. FEMS Microbiol Rev

$18 \quad 16: 221-231$

19 3. Tanaka T, Hoshina M, Tanabe S, Sakai K, Ohtsubo S, Taniguchi M (2006) Production

20 of D-lactic acid from defatted rice bran by simultaneous saccharification and

21 fermentation. Bioresour Technol 97:211-217 
1 4. Brizzolara D, Cantow H, Diederichs K, Keller E, Domb A (1996) Mechanism of the

2 stereocomplex formation between enantiomeric poly(lactide)s. Macromolecules 29:191$3 \quad 197$

4 5. Ikada Y, Jamshidi K, Tsuji H, Hyon S (1987) Stereocomplex formation between 5 enantiomeric poly (lactides). Macromolecules 20:904-906

6 6. Tsuji F (2002) Autocatalytic hydrolysis of amorphous-made polylactides: effects of L-

7 lactide content, tacticity, and enantiomeric polymer blending. Polymer 43:1789-1796

8 7. Yadav AK, Chaudhari AB, Kothari RM (2011) Bioconversion of renewable resources

9 into lactic acid: an industrial view. Crit Rev Biotechnol 31:1-19

10 8. Vadlani PV, Mathews AP, Karr GS (2008) Low-cost propionate salt as road deicer:

11 evaluation of cheese whey and other media components. World J Microbiol Biotechnol $12 \quad 24: 825-832$

13 9. Vadlani PV, Matthews AP, Karr GS (2008) A two-stage fermentation process: 14 production of propionate and acetate salt as road deicer from cheese whey. Biological 15 Engineering 1:95-104

16 10. Moon SK, Lee J, Song H, Cho JH, Choi GW, Seung D (2012) Characterization of 17 ethanol fermentation waste and its application to lactic acid production by Lactobacillus 18 paracasei. Bioprocess Biosyst Eng. Doi: 10.1007/s00449-012-0810-5

19 11. Phrueksawan P, Kulpreecha S, Sooksai S, Thongchul N (2012) Direct fermentation of $20 \mathrm{~L}(+)$-lactic acid from cassava pulp by solid state culture of Rhizopus oryzae. Bioprocess 21 and Biosyst Eng. 35:1429-1436

22 12. Fukushima K, Sogo K, Miura S, Kimura Y (2004) Production of D-lactic acid by 23 bacterial fermentation of rice starch. Macromolecular Bioscience 4:1021-1027 
1 13. Yanez R, Moldes AB, Alonso JL, Parajo JC (2003) Production of D-lactic acid from

2 cellulose by simultaneous saccharification and fermentation using Lactobacillus

3 coryniformis subsp torquens. Biotechnol Lett 25:1161-1164

4 14. Tashiro Y, Kaneko W, Sun Y, Shibata K, Inokuma K, Zendo T, Sonomoto K (2011)

5 Continuous D-lactic acid production by a novel thermotolerant Lactobacillus delbrueckii

6 subsp lactis QU 41. Appl Microbiol Biotechnol 89:1741-1750

7 15. Shinkawa S, Okano K, Tanaka T, Ogino C, Kondo A (2009) Efficient D-lactic acid

8 production from raw starch. J Biosci Bioeng 108:S47-S48

9 16. Schmidt S, Padukone N (1997) Production of lactic acid from wastepaper as a

10 cellulosic feedstock. J Ind Microbiol Biotechnol 18:10-14

11 17. Xu Z, Wang Q, Jiang Z, Yang X, Ji Y (2007) Enzymatic hydrolysis of pretreated 12 soybean straw. Biomass \& Bioenergy 31:162-167

13 18. Marques S, Santos JAL, Girio FM, Roseiro JC (2008) Lactic acid production from 14 recycled paper sludge by simultaneous saccharification and fermentation. Biochem Eng J $15 \quad 41: 210-216$

16 19. Kim K, Kim W, Seo D, Yoo I, Kim E, Yoon H (2003) Production of lactic acid from 17 food wastes. Appl Biochem Biotechnol 105:637-647

18 20. Yanez R, Alonso JL, Parajo JC (2005) Study on the suitability of untreated 19 corrugated cardboard for D-lactic acid production by SSF using Lactobacillus 20 coryniformis subsp torquens. Afinidad 62:295-301

21 21. Yanez R, Alonso JL, Parajo JC (2005) D-Lactic acid production from waste

22 cardboard. J Chem Technol Biotechnol 80:76-84 
1 22. Wang L, Zhao B, Li F, Xu K, Ma C, Tao F, Li Q, Xu P (2011) Highly efficient

2 production of D-lactate by Sporolactobacillus sp. CASD with simultaneous enzymatic

3 hydrolysis of peanut meal. Appl Microbiol Biotechnol 89:1009-1017.

4 23. Biermann CJ (1996) Handbook of pulping and papermaking. Elsevier Science, San 5 Diego.

6 24. Li Y, Ruan R, Chen PL, Liu Z, Pan X, Lin X, Liu Y, Mok CK, Yang T (2004)

7 Enzymatic hydrolysis of corn stover pretreated by combined dilute alkaline treatment and

8 homogenization. Trans ASAE 47:821-825

9 25. Calabia BP, Tokiwa Y (2007) Production of D-lactic acid from sugarcane molasses,

10 sugarcane juice and sugar beet juice by Lactobacillus delbrueckii. Biotechnol Lett $11 \quad 29: 1329-1332$

12 26. Ghose T (1987) Measurement of cellulase activities. Pure Appl Chem 59:257-268

13 27. Mukhopadhyay A,Bioconverstion of paper mill lignocellulosic materials to lactic acid 14 using cellulase enzyme complex and microbial cultures. [MS Thesis].Manhattan, 15 KS:Kansas State University; 2009. Available from: K-State Research Exchange

16 28. Lee Y, Fan L (1982) Kinetic-studies of enzymatic-hydrolysis of insoluble cellulose 17 analysis of the initial rates. Biotechnol Bioeng 24:2383-240624

18 29. Chandra RP, Au-Yeung K, Chanis C, Roos AA, Mabee W, Chung PA, Ghatora S,

19 Saddler JN (2011) The influence of pretreatment and enzyme loading on the effectiveness

20 of batch and fed-batch hydrolysis of corn stover. Biotechnol Prog 27:77-85

21 30. Demirci A, Pometto AL (1992) Enhanced production of D-lactic acid by mutants of 22 Lactobacillus delbrueckii ATCC 9649. J Ind Microbiol 11:23-28 
1 31. Okano K, Yoshida S, Yamada R, Tanaka T, Ogino C, Fukuda H, Kondo A (2009)

2 Improved production of homo-D-Lactic acid via xylose fermentation by introduction of

3 xylose assimilation genes and redirection of the phosphoketolase pathway to the pentose

4 phosphate pathway in L-Lactate dehydrogenase gene-deficient lactobacillus plantarum.

$5 \quad$ Appl Environ Microbiol 75:7858-7861

6 32. Zhao B, Wang L, Li F, Hua D, Ma C, Ma Y, Xu P (2010) Kinetics of D-lactic acid

7 production by Sporolactobacillus sp strain CASD using repeated batch fermentation.

8 Bioresour Technol 101:6499-6505

9 33.Garde A, Jonsson G, Schmidt AS, Ahring BK (2002) Lactic acid production from

10 wheat straw hemicellulose hydrolysate by Lactobacillus pentosus and Lactobacillus

11 brevis. Bioresour Technol 81(3):217-223

12 34. Patel M, Ou M, Harbrucker R, Aldrich H, Buszko M, Ingram L, Shanmugam KT

13 (2006) Isolation and characterization of acid-tolerant, thermophilic bacteria for effective

14 fermentation of biomass-derived sugars to lactic acid. Appl Environ Microbiol 72:3228-

$15 \quad 3235$

16 35. Parajo J, Alonso J, Moldes A (1997) Production of lactic acid from lignocellulose in a

17 single stage of hydrolysis and fermentation. Food Biotechnol 11:45-58

18 36. Nakasaki K, Adachi $\mathrm{T}$ (2003) Effects of intermittent addition of cellulase for

19 production of L-lactic acid from waste water sludge by simultaneous saccharification and

20 fermentation. Biotechnol Bioeng 82:263-270

21 37. Akerberg C, Zacchi G (2000) An economic evaluation of the fermentative production

22 of lactic acid from wheat flour. Bioresour Technol 75:119-126 
1 38. Boonmee M, Leksawasdi N, Bridge W, Rogers P (2003) Batch and continuous

2 culture of Lactococcus lactis NZ133: experimental data and model development.

$3 \quad$ Biochem Eng J 14:127-135

4 39. Nandasana AD, Kumar S (2008) Kinetic modeling of lactic acid production from

5 molasses using Enterococcus faecalis RKY1. Biochem Eng J 15:277-284

6 40. Amrane A (2005) Analysis of the kinetics of growth and lactic acid production for

7 Lactobacillus helveticus growing on supplemented whey permeate. J Chem Technol

8 Biotechnol 80:345-352

9 
1 Table 1 D-lactic acid production through SHF and SSF process in shake flask

\begin{tabular}{lllllll}
\hline & $\mathrm{C}_{0}{ }^{\mathrm{a}}$ & $\mathrm{C}_{\mathrm{P}}{ }^{\mathrm{b}}$ & $Y_{\mathrm{PS}}{ }^{\mathrm{c}}$ & $Y_{\mathrm{PS}}{ }^{\mathrm{d}}$ & $\mathrm{Q}_{\mathrm{P}}{ }^{\mathrm{e}}$ \\
\hline SHF & $\begin{array}{l}\text { Synthetic } \\
\text { medium }\end{array}$ & 10 & $7.7 \pm 0.05$ & $0.77 \pm 0.01$ & --- & $0.25 \pm 0.01$ \\
& & & & & \\
& $\begin{array}{l}\text { Pulp } \\
\text { Modified }\end{array}$ & $9.7 \pm 0.17$ & $7.5 \pm 0.47$ & $0.77 \pm 0.66$ & $0.38 \pm 0.02$ & $0.25 \pm 0.03$ \\
& $11.2 \pm 0.09^{*}$ & $8.5 \pm 0.39$ & $0.76 \pm 0.03$ & $0.42 \pm 0.02$ & $0.28 \pm 0.01$ \\
& $\begin{array}{l}\text { pulp } \\
\text { Corn }\end{array}$ & $9.9 \pm 0.05$ & $8.3 \pm 0.04$ & $0.83 \pm 0.01$ & $0.41 \pm 0.01$ & $0.27 \pm 0.01$ \\
& & & & & $0.48 \pm 0.04^{*}$ & $0.31 \pm 0.04$ \\
stover & & $19.2 \pm 1.63^{*}$ & --- & $0.58 \pm 0.03^{*}$ & $0.32 \pm 0.07$ \\
\hline SSF & $\begin{array}{l}\text { Pulp } \\
\text { Corn }\end{array}$ & --- & $20.1 \pm 0.65^{*}$ & --- & & \\
\hline
\end{tabular}

2 Each mean is based on three replications ( $\mathrm{p}<0.05$; REGWQ; one-way ANOVA)

$3 \quad{ }^{\mathrm{a}}$ Initial glucose of modified pulp hydrolyzate was significantly different

$4 \quad{ }^{b}$ D-lactic acid concentration in SSF process was significantly different in SHF process

$5 \quad{ }^{\mathrm{c}}$ Product yield was not significantly different in SHF process; product yield was calculated by the amount 6 of D-lactic acid produced divided by the amount of glucose consumed.

$7 \quad{ }^{\mathrm{d}}$ Product overall yield was significantly different between SSF and SHF; product overall yield was

8 calculated by the amount of D-lactic acid produced divided by the amount of biomass used.

$9 \quad{ }^{\mathrm{e}}$ Productivity was not significantly different.

11 Table 2 Kinetic parameters of different lactic acid bacteria

\begin{tabular}{lllll}
\hline Microorganism & Substrate & $\mu_{\max }$ & $\alpha$ & $\beta$ \\
\hline $\begin{array}{l}\text { L. delbrueckii } \\
\text { (this study) }\end{array}$ & Glucose & 0.2 & 7.8 & 0.18 \\
$\begin{array}{l}\text { L. lactis [38] } \\
\begin{array}{l}\text { E. faecalis } \\
\text { RKY1 [39] }\end{array}\end{array}$ & Lactose & 1.1 & 0.392 & 3.02 \\
$\begin{array}{l}\text { Lactobacillus } \\
\text { helveticus [40] }\end{array}$ & Whey permeate & 0.48 & 0.26 & --- \\
\hline
\end{tabular}

13 Table 3 Kinetic parameters of fed-batch and batch fermentation

\begin{tabular}{lcccccc}
\hline & $\mathrm{C}_{\mathrm{p}}$ & $Y_{\mathrm{PS}}$ & $Y_{\mathrm{PX}}$ & $Y_{\mathrm{XS}}$ & $\mathrm{q}_{\mathrm{PS}}$ & $\mathrm{Q}_{\mathrm{P}}$ \\
\hline Fed-batch (stage I) & 37.4 & 0.93 & 10.9 & 0.086 & 0.026 & 1.04 \\
Pulp hydrolyzate batch & 36.3 & 0.83 & --- & -- & 0.023 & 1.01 \\
\hline
\end{tabular}




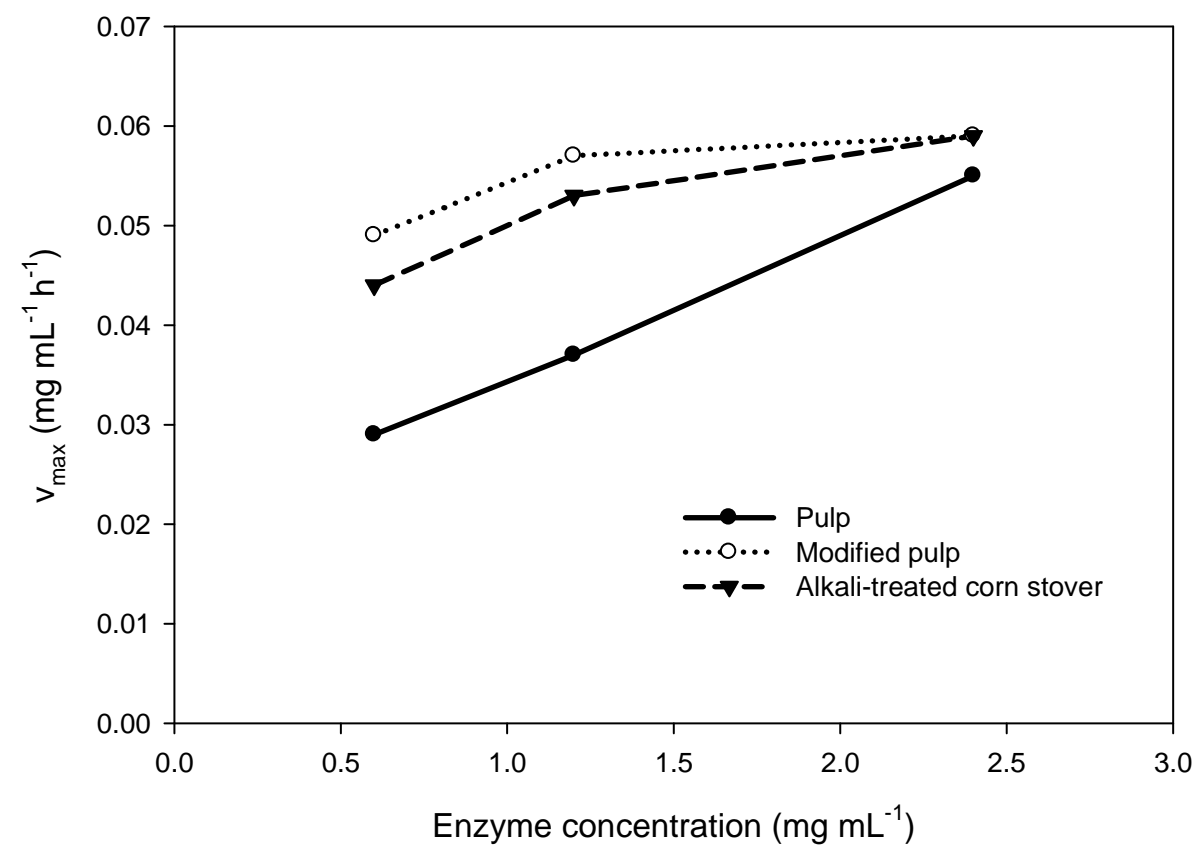

1 Fig. 1 Plot of $v_{\max }$ of different biomass versus enzyme concentration

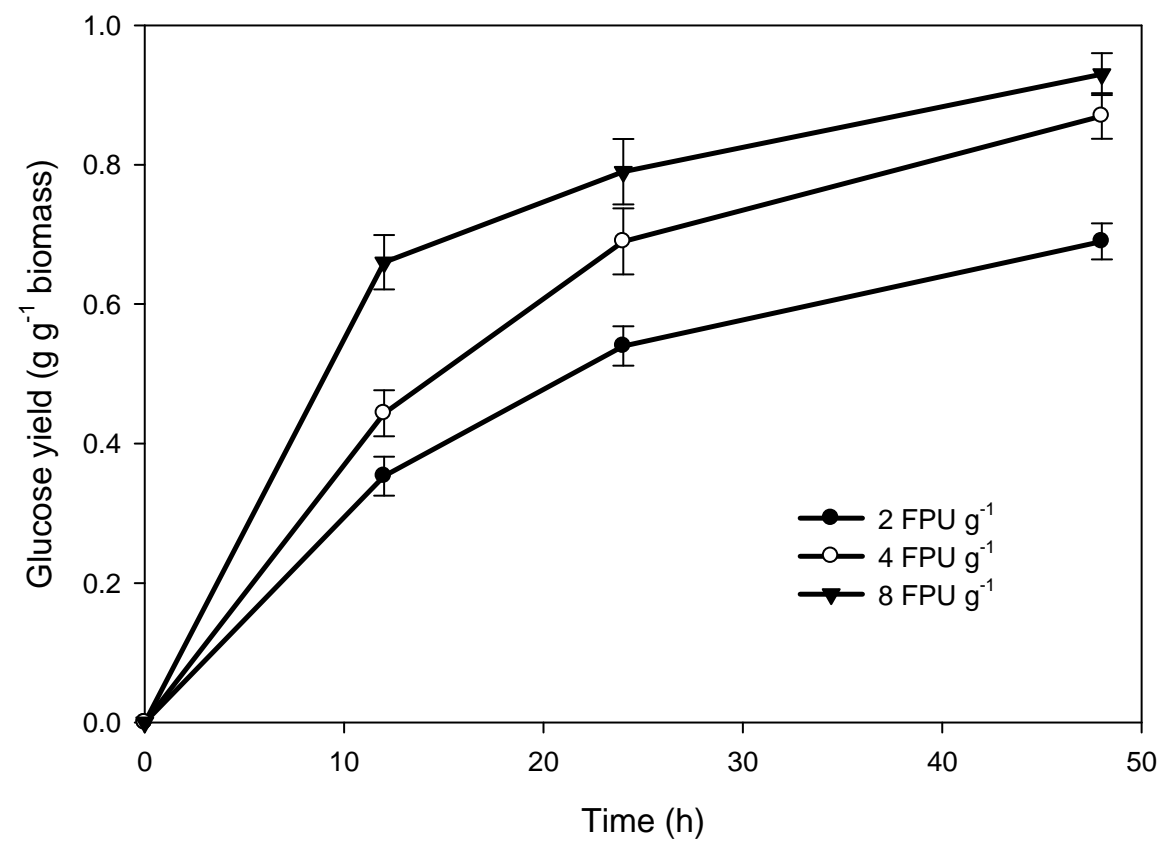

3
4

(a) 

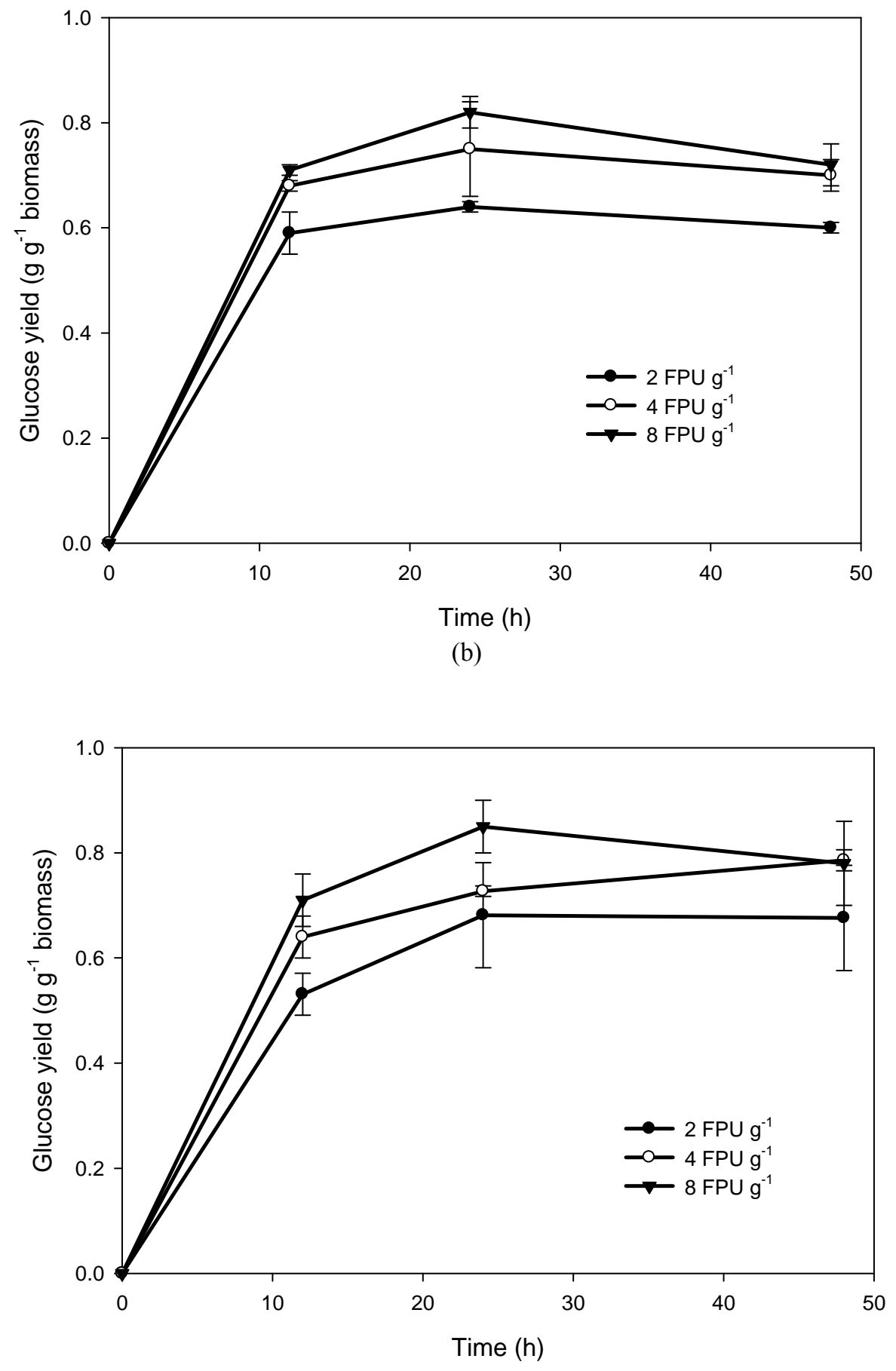

(c)

Fig. 2 Enzymatic hydrolysis of pulp (a), mechanically modified pulp (b), and alkali-treated corn stover (c) at varying cellulase levels 


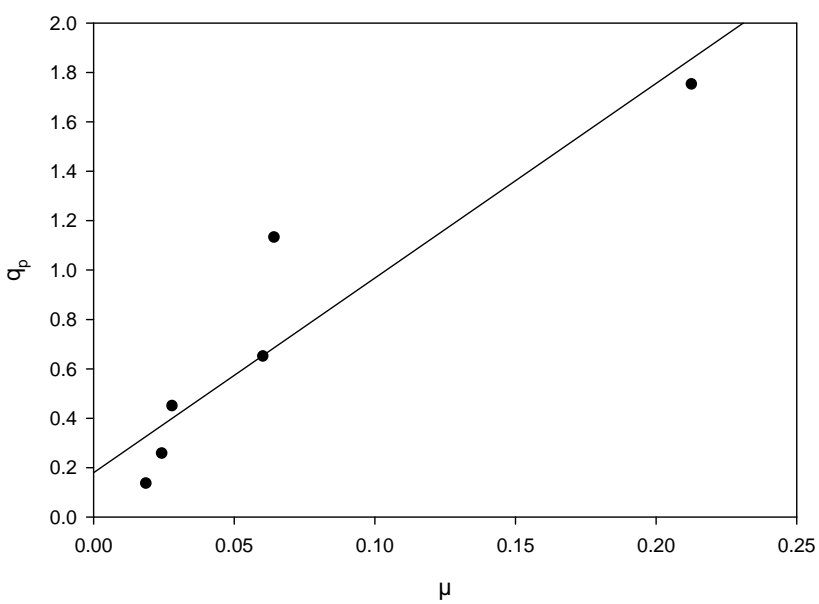

2 Fig. 3 Specific production rate versus specific growth rate for $L$. delbrueckii growing on the synthetic 3 medium

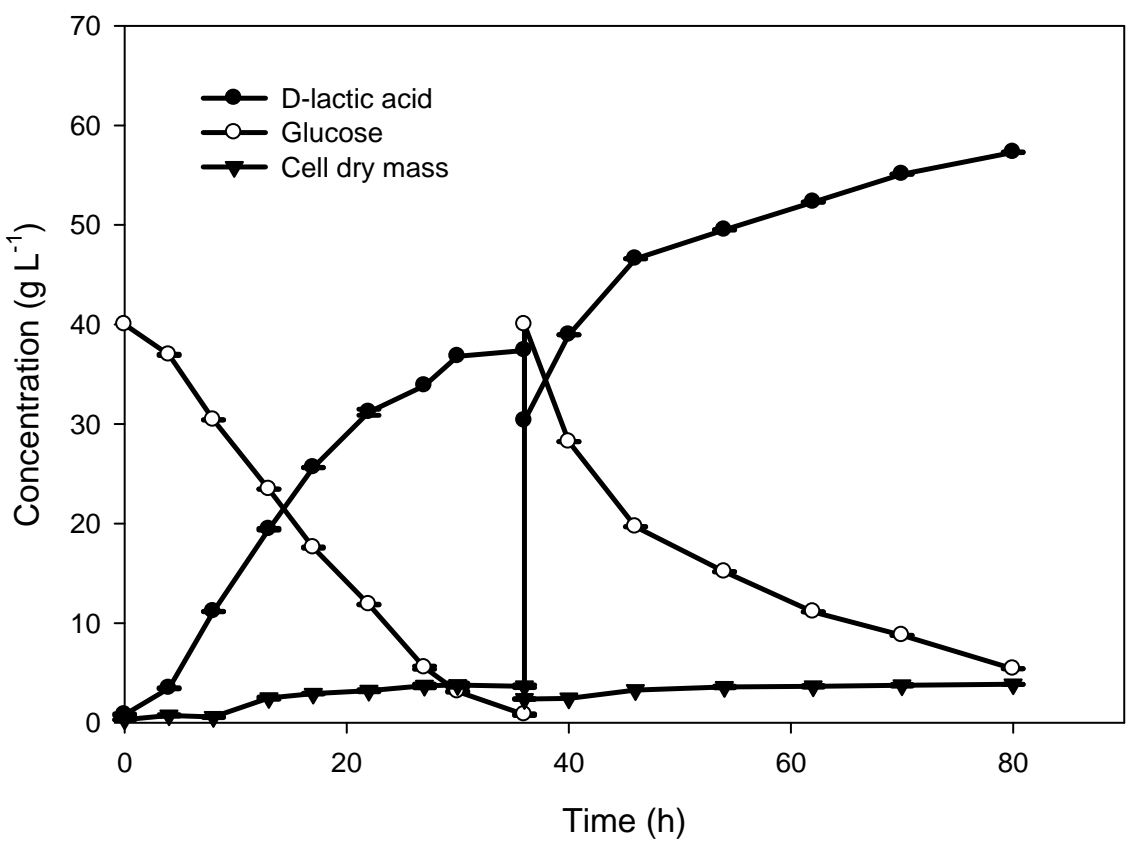

6 Fig. 4 Fed-batch fermentation profile of D-lactic acid from the synthetic medium 


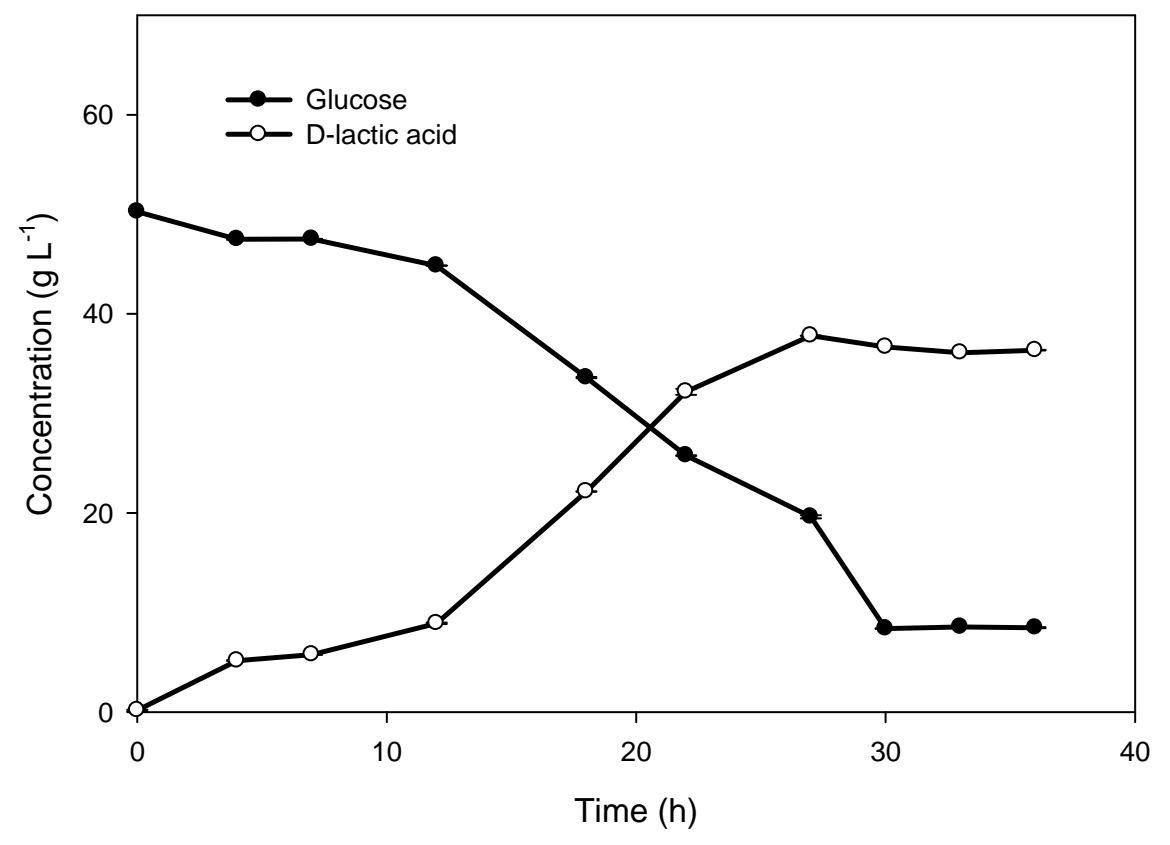

2 Fig. 5 Batch fermentation profile of D-lactic acid production from pulp hydrolyzate

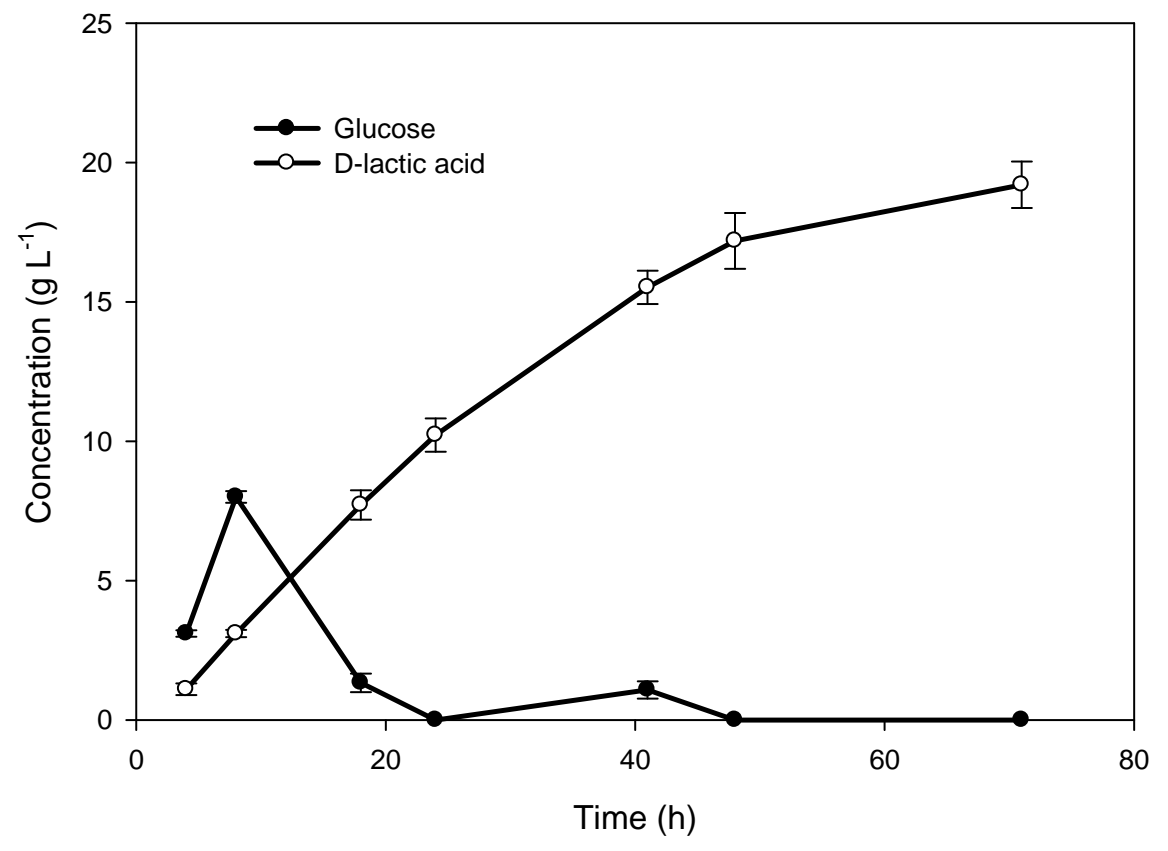

(a) 


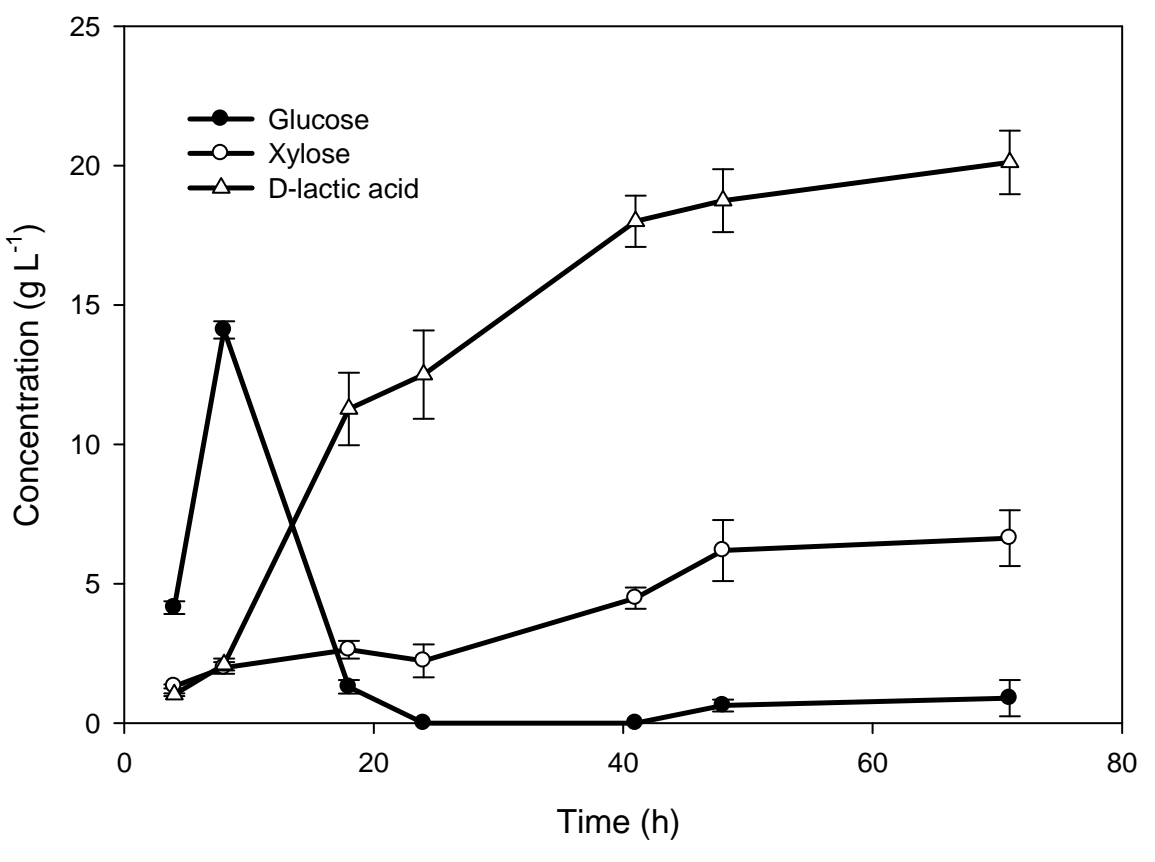

$\begin{array}{ll}2 & \text { (b) } \\ 3 & \text { Fig. } 6 \text { Time course of SSF process with L.delbrt }\end{array}$

Fig. 6 Time course of SSF process with L.delbrueckii using pulp (a) and alkali-treated corn stover (b) 